\title{
The Determinants of Bank Stock Prices: A Panel Approach
}

\author{
Sajid Ali * $\quad$ Taqadus Bashir ${ }^{\dagger} \quad$ Tanveer Ahmed ${ }^{\ddagger} \quad$ Adeeba Ishaq ${ }^{\S}$ \\ Syed Jawad Hussain Shahzad ฯ
}

\begin{abstract}
The current study used panel data to empirically analyze the determinants of stock prices and for that monthly closing stock prices of eight main banks of Pakistan were taken for the period from January 2005 till December 2013. Various unit root and cointegration techniques were employed for analysis besides Granger Causality. The results indicated increase in share prices in response to boom in economic activity, whereas bank share prices declined in response to currency depreciation and interest rate increase. Furthermore, in long-run, Granger causality is witnessed among economic growth, nominal exchange rate and bank stock prices. Interest rate and bank stock prices Granger cause each other and hence, exhibit a bi-directional causality. The findings of the current study have significant implications for portfolio advisors, risk management framework of banks and their regulators.
\end{abstract}

Keywords: Interest rate, nominal exchange rate, cointegration, risk management, banks

\section{Introduction}

The determinants of stock prices, keeping in view an immense importance of stock markets in the growth and prosperity of an economy, have extensively been examined. Various studies have documented that economic condition of a country is assessed from the activity on its stock market. Recent volatility conditions in financial markets in past few years and howsoever financial market liberalization has not only facilitated the operations of majority financial institutions in foreign markets but also exposed them to massive interest rate risk. The viability of banks is adversely affected as this impact cannot be eradicated even through risk managing techniques (Gilkeson \& Smith, 1992). Meanwhile the financial institutions not fully undergone internalization process, are facing varying degree of interest and exchange rate sensitivity among them whereby the operations and nationality of those banks are also contributing. The unanticipated movements in exchange and interest rates and disparity between the maturity of bank's assets and liabilities are key elements bringing increase in bank's risk exposure. Majority economists and financial experts have

\footnotetext{
* Department of Management Sciences, Bahria University, Islamabad, Pakistan.

E-mail: sajid.mahr@gmail.com

${ }^{\dagger}$ Department of Management Sciences, Bahria University, Islamabad, Pakistan.

E-mail: doc.tbc.tabs@gmail.com

${ }^{\ddagger}$ Air University School of Management (AUSOM), Air University, Islamabad, Pakistan.

$\S$ Pakistan Institute of Development Economics, Islamabad, Pakistan Quaid-e-Azam University, Pakistan.

\Energy and Sustainable Development (ESD), Montpellier Business School, Montpellier, France.
} 
consensus over the notion that unanticipated change in interest and exchange rates have direct influence on the costs, revenues and profitability of banks. Furthermore, bank's stock returns also take effect of their nominal assets and liability holdings through wealth distribution influences created by unexpected inflation (Saunders \& Yourougou, 1990).

The nominal contracting hypothesis (French, Ruback, \& Schwert, 1983; Bach \& Ando, 1957; Kessel, 1956) states that the two main balance sheet components i.e. nominal assets and liabilities of banks sensitize their stock returns towards interest rate change (Flannery \& James, 1984). Additionally, it assumes that unanticipated inflation transfers the lender's wealth to borrowers and banks bearing high nominal liabilities benefit more than the ones having more nominal assets and vice versa. Choi, Elyasiani, and Kopecky (1992) identified nature of banking sector as the major root cause of interest rate risk impact over their stock prices. Kwan (1991) states that the stock prices generated by the real assets of the firms, according to the fundamental cash flow discounted model, depend on the discounted cash flows. However, the banking sector cash flows are determined by the nominal assets that are fixed in nominal terms, for instance, cash, debt and account receivables (Kwan, 1991; Yourougou, 1990; Saunders \& Yourougou, 1990). Hence, the share prices of banking sector as compared to manufacturing firms are found to be more sensitive to interest rate changes.

The price sensitivity of stocks towards exchange rates and interest rate fluctuation varies among all banks, where nationality of banks coupled with its nature of operations are main contributors towards the degree of banking sector stock price sensitivity. And all this is due to the incomplete process of financial institutions (FIs) internalization. The unanticipated interest and exchange rate fluctuations increase risk exposure of banks and create imbalance between their assets and liabilities. These two key contributors also have impact on the profitability, revenues and costs borne by banks (Saunders \& Yourougou, 1990) The diversity in bank operations offered in various countries as a result of financial institutions internalization exposes them to the exchange rate risk, thereby making it a common risk element for FIs (Viale, Kolari, \& Fraser, 2009). Gilkeson and Smith (1992) are of the opinion that even the most effective risk management approaches cannot completely eradicate the exchange rate and interest rate risks due to the exposure of these banks towards foreign exchange, rather these risks adversely affect the capability of the banks operating across border.

During the past four decades, the financial system in Pakistan has undergone variety of regulatory reforms. In beginning of 70s, financial institutions including local banks faced the nationalization process and this nationalization was completed by 1974 . Nevertheless, foreign banks remained operational throughout the process but operated with limited number of branches and had an insignificant market share. Meanwhile, majority public sector banks faced monetary inefficiencies that resulted in corroding quality of their assets. In appropriation to all this wake, grave risk of financial distress was accumulating gradually. In late 1980s, it became very much evident that nationalization was not the solution to attain goals established for nation-wide social and economic growth. So that was the time when banking sector and financial institutions and markets were endorsed for liberalization development (Khan \& Aftab, 1994; Haque, 1997). Liberalization of foreign exchange controls was initialized by regulatory authorities in beginning of 90 s and at the same time, 
foreign currency accounts in banks were opened for all residents and non-residents. Also, the domestic private banks were permitted to obtain license for operations and ten new banks were given. At the same time two large public owned banks, namely Allied Bank of Pakistan (ABP) and Muslim Commercial Bank (MCB) holding 14\% of whole loan market share got privatized. Later by the end of 90s, banking system in Pakistan experienced serious changes in order to adopt best international financial practices for aligning them with rest of world and till then 21 local whereas 27 foreign banks were operational. Banking system in Pakistan, bearing a diversified structure, grab one's attention to qualify for exploring the combined influence of exchange rate and interest rate variations on stock prices of banking sector for helping the regulatory bodies in forming policies.

Various risk management procedures are implemented across the world to moderate bank's exposure to the exchange and interest rate shocks. Nevertheless, lack of knowledge about these techniques and inadequate system to implement them in emerging markets has more damaging effect on their financial institutions. Such situations lead the financial institutions to face financial distress in emerging and developing economies and it becomes imperative to investigate the sensitivity phenomenon of their stock prices in response to variations in interest and exchange rate risks. Although, number of studies have examined the reaction of bank stock prices to interest and exchange rate fluctuations individually, however, literature on the joint impact of interest and exchange rate movements on banks stock prices is scarce. Therefore, the key contribution of the current study is to analyze the joint effect of both the variables on bank stock prices. Further, the study analyzes the applicability of Intertemporal Capital Asset Pricing Model (ICAPM) and the nominal contracting hypothesis by employing panel data approach on monthly stock prices of eight major Pakistani banks. The study found the evidence that boom in economic activity bring surge in share prices of banks, whereas these prices are lowered in response to incline in interest rate and depreciation of currency. Furthermore, share prices of banks are Granger caused by nominal exchange rates and economic performance, and a bidirectional causality is witnessed between interest rate and share prices of banking sector.

\section{Literature Review}

Flannery and James (1984) detected inverse relationship between interest rate changes and investments in equity markets when examined the theoretical foundation of this relationship based upon nominal contracting hypothesis. They chose interest rates as the proxy of opportunity cost for stock investments. The nominal contract signifies the agreement made by two parties for exchange of fixed payment at some future point of time/date. For the present valuation of future payments, the anticipated inflation that can possibly occur for the duration of contract is considered by parties in contract. But, in case of unanticipated inflation, the wealth however would be distributed from lender to borrower (Kessel \& Alchian, 1960). The relationship is inverse between unanticipated inflation and stock prices in case nominal assets of a firm are lesser than its nominal liabilities (vice versa for otherwise), where balance sheet composition moderates this relationship. Interest rate variation takes place may the inflation be anticipated or unanticipated; and conclusively 
has negative impact on stock returns (Flannery \& James, 1984).

Merton (1973) proposed an Intertemporal Capital Asset Pricing Model (ICAPM) for determining bank's stock sensitivity in response to interest rate change. Flannery, Hameed, and Harjes (1997) suggested to use the interest rate variation as an alternative for transferal in investment prospect. Yourougou (1990) stated that if selection option between two assets or portfolios is presented to an investor where both assets have similar features including equal future wealth disbursement coupled with differing response to interest rate variations, the risk-avoiding investor will favor the portfolio or asset that has relatively superior hedging features against unfavorable movements in interest rate. This finding empirically supported the research sensitivity presence since long purported and presented by Fama and Schwert (1977) as they empirically concluded that explanatory power of single factor model is significantly improves after addition of interest rate to it.

Similarly, Bae (1990) also tested and detected a substantial inverse association between anticipated and unanticipated interest rate variations and stock returns of banking sector. Bulmash and Trivoli (1991) took data from financial institutions of USA market and found similar trend in relationship between interest rate change and stock prices. Moreover, various studies examined and found negative influence of interest rate changes on stock returns of banks (Scott \& Peterson, 1986; Flannery \& James, 1984; Booth \& Officer, 1985; Lynge \& Zumwalt, 1980). On the contrary, many studies documented significant positive relationship between same set of variables (Asprem, 1989; Apergis \& Eleftheriou, 2002). Shiller and Beltratti (1992) suggested reasons for this positive association and opined that increase in interest rate bring surge in dividends and that further leads to growth in stock prices. Whereas, examinations by Chance and Lane (1980) and Lloyd and Shick (1977) failed to detect any significant relation between the interest rate and stock prices.

Despite availability of extensive literature on sensitivity phenomenon of interest rate, relatively meager evidence can be found analyzing banking sector stock return sensitivity in response to exchange rate. Dornbusch and Fischer (1980) presented theory of goods market approach in an attempt to elaborate this particular association between exchange rate sensitivity and its impact on stock returns of manufacturing firms. An inverse relationship is established by the theory between exchange rate and stock returns in case of a country that heavily depends on exports. The reason identified is that in case native currency appreciates, it will cause the prices of products to climb in foreign market in turn affecting the export attractiveness abroad and thus pulling down the earnings of particular firm. On the contrary, the appreciation in the native currency of heavily import-dependent nation will bring down the firm's manufacturing cost, thereby escalating the earnings and thus benefitting the local stock returns due to progressive impact of exchange rate.

In addition to this, the impact of exchange rate fluctuations on portfolio returns can also be understood through the world popular portfolio theory by Markowitz (1952). As, currency depreciation of native countries decreases the foreign investors' returns while transforming it to their own home-based money. This ultimately leads them to switch the asset allocation to another foreign market from the depreciated one. Contrarily, the same depreciation of native currency converts the foreign stocks into costly ones for the native investors and they feel compelled to withdraw money from foreign and buy more of local stocks thereby booming the prices of local stocks. Totally opposite is the effect of 
exchange rate in the case of native currency appreciation. In nutshell, stock markets take both type of effects from variations in exchange rates. Saldanli, Aydin, and Bektas (2017) used monthly data to examine the impact of exchange rate fluctuations on 10 banking sector stocks listed on Istanbul Stock Exchange. The study identified exchange rate as one causal factor after panel data causality test was applied.

Two different studies conducted at different points of time by Chamberlain, Howe, and Popper (1997) and Grammatikos, Saunders, and Swary (1986) had same findings and concluded that exchange rate risk has impact on USA bank stocks. Chamberlain et al. (1997) selected daily and monthly sample data from banks in Japan and US to test their sensitivity towards exchange rates and found that majority bank stocks in USA were sensitive to exchange rate volatility. However, majority banks listed on stock exchanges in Japan were found to be immune to exchange rate shocks. Conversely, Zhao (2010) found no significant association between exchange rate volatility and Chinese bank stocks.

Majority studies exploring the determinants of banking sector stock sensitivity examined each factor in isolation i.e. variation effect of exchange rates and interest rate independently and very less studies investigated the joint impact of these two variables. For example, both Wetmore and Brick (1994) and Choi et al. (1992) analyzed the combined effect of exchange rates, interest and market on stock prices of banking sector. Choi et al. (1992) tested USA banking sector and found them to be more sensitive towards variations in interest rates as compared to changes in exchange rates. Whereas, Wetmore and Brick (1994) tested and found opposite in case of Korean Banking sector stock. Interestingly, Hahm (2004) concluded for same market that bank stocks were responsive to all the three factors mentioned above. In context of India, Narayan, Narayan, and Singh (2014) investigated the response of banking sector stock prices for economic events and exchange and interest rates. Their examination revealed that interest rates affected negatively whereas good economic conditions and exchange rate variations had positive influence.

As expected, the above literature review provides contradicting findings on the relationship between interest and exchange rate fluctuations and banking sector stock prices. Moreover, lesser evidence based investigation on the combined impact of these factors towards banking sector stock prices responsiveness is present. However, it is even more meager in case of emerging economies. Hence, this research aimed to explore the joint effect of exchange and interest rate variations as well as the stock market on an emerging economy's i.e. Pakistan banking sector stock prices.

\section{Methodology}

The study aimed to examine the effect of variations in interest rate, exchange rates and stock market index as determinants of stock prices movements of banking sector. Eight leading banks of Pakistan were chosen for data. Sample consisted of Bank Alfalah Limited (BAFL), Bank of Punjab (BOP), National Bank of Pakistan (NBP), Meezan Bank Limited (MBL), Muslim Commercial Bank (MCB), Faysal Bank Limited (FBL), Bank Al-Habib Limited (BAHL) and NIB Bank Limited. Stock market index is taken as an economic activity indicator, ninety days' average interest rate and nominal exchange rates 
i.e. Pakistani Rupee to American Dollar are employed. The panel version of an interest rate equation can be expressed as under:

$$
\ln S P_{i t}=\beta_{0}+\beta_{1} \ln E R_{i t}+\beta_{2} \ln I R_{i t}+\beta_{3} \ln M R K_{i t}+\varepsilon_{i t}
$$

where, SP, ER, IR and MRK indicate bank stock prices, nominal exchange rate, ninetydays nominal interest rate and stock market (KSE100 Index), respectively. Subscript i represents all the banks from 1 to 8 , whereas $\mathrm{t}=$ signifies time from January 2005 till December 2013 constituting monthly data. A total of 108 observations for each individual bank and 864 for the complete panel have been collected reflecting sufficient size for panel for carrying out the econometric analysis. All the data was sourced from DataStream International.

\section{Empirical Results and Analysis}

\section{Descriptive Statistics}

Table 1 shows the mean and standard deviation for monthly stock prices and returns of all the eight banks. The monthly average value and standard deviation for KSE 100 index (market) are 12141.96 and 4167.24, respectively. Among selected banks, MCB remained highest with monthly average stock prices of 218.07 and higher standard deviation of $78.23 \%$. Following MCB, higher average stock price was found to be of NBP at 119.09 with highest most deviation of $83.86 \%$. Lowest average stock was found to be of NIB Bank with average at 11.12 and standard deviation of $10.20 \%$. The lowest most standard deviation was found for Meezan Bank i.e. 8.33\%. the overall descriptive statistics show that the highest returning stocks have higher risk or standard deviation as well.

\section{Results of Unit Root Tests}

Before proceeding further, Breitung (2001) approach has been adopted and stationarities of all the time series under study were calculated at log-level as well as first-difference. Table 2 demonstrates the coefficients of both for all the eight bank stock price series. Optimal lag length was decided upon Schwarz information criteria and unit root was detected at log-level for all the four variables. Whereas, the null hypothesis for unit root presence was rejected strongly at first difference for all variables. Same conclusion can be drawn for integration properties in case of all variables in panel after applying the LLC test of Im, Pesaran, and Shin (2003) and Levin, Lin, and Chu (2002). Upon finding all monthly series integrated of order one i.e. I(I), next stage is to apply cointegration tests in order to detect cointegrating roots among the variables under study. 
Table 1

Descriptive statistics

\begin{tabular}{lcccc}
\hline & \multicolumn{2}{c}{ Stock Prices } & \multicolumn{2}{c}{ Stock Returns } \\
\hline & Mean & Std. Dev. & Mean & Std. Dev. \\
\hline BAFL & 29.41 & 19.57 & 0.0065 & 0.130 \\
BAHL & 43.39 & 17.01 & 0.0049 & 0.105 \\
BOP & 42.45 & 41.45 & -0.0003 & 0.169 \\
FBL & 32.28 & 25.65 & 0.0004 & 0.134 \\
MCB & 218.07 & 78.23 & 0.0236 & 0.127 \\
MBL & 23.42 & 8.33 & 0.0142 & 0.112 \\
NBP & 119.09 & 83.86 & 0.0100 & 0.150 \\
NIB & 11.12 & 10.2 & -0.0071 & 0.161 \\
ER (PKR/USD) & 77.65 & 14.99 & 0.0055 & 0.0120 \\
IR (T Bills) & 10.35 & 2.19 & 0.0100 & 0.048 \\
KSE 100 Index (Market) & 12141.96 & 4167.24 & 0.0172 & 0.078 \\
\hline Note: Std. Dev., ER and IR indicate standard deviation, exchange \\
rate and interest rate, respectively.
\end{tabular}

Table 2

Results of Panel Unit Root Tests

\begin{tabular}{|c|c|c|c|c|}
\hline & \multicolumn{2}{|c|}{ (Levin et al., 2002) } & \multicolumn{2}{|c|}{ (Im et al., 2003) } \\
\hline & \multicolumn{2}{|c|}{ Intercept } & \multicolumn{2}{|c|}{ Intercept } \\
\hline & Level & First diff. & Level & First diff. \\
\hline SP & $-0.456(1)$ & $-34.005^{* * *}(0)$ & $0.629(1)$ & $-30.471^{* * *}(0)$ \\
\hline ER & $2.576(1)$ & $-20.992^{* * *}(0)$ & $5.614(1)$ & $-17.215^{* * *}(0)$ \\
\hline IR & $3.634(0)$ & $-19.219^{* * *}(0)$ & $-1.945(0)$ & $-18.737 * * *(0)$ \\
\hline \multirow[t]{3}{*}{ MKR } & $2.908(0)$ & $-28.433 * * *(0)$ & $3.006(0)$ & $-24.681^{* * *}(0)$ \\
\hline & \multicolumn{2}{|c|}{ Intercept \& Trend } & \multicolumn{2}{|c|}{ Intercept \& Trend } \\
\hline & Level & First diff. & Level & First diff. \\
\hline $\mathrm{SP}$ & $1.191(1)$ & $-38.287^{* * *}(0)$ & $1.573(1)$ & $-31.416^{* * *}(0)$ \\
\hline ER & $0.131(1)$ & $-23.766^{* * *}(0)$ & $0.691(1)$ & $-16.819^{* * *}(0)$ \\
\hline IR & $-7.738^{* * *}(0)$ & $-22.827^{* * *}(0)$ & $-1.011(0)$ & $-20.057 * * *(0)$ \\
\hline MKR & $2.893(0)$ & $-33.414^{* * *}(0)$ & $3.478(0)$ & $-25.127 * * *(0)$ \\
\hline
\end{tabular}

\section{Cointegration Analysis}

The residual based panel cointegration procedures proposed by Kao (1999) and Pedroni (1999, 2004) were employed for panel cointegration analysis of stock prices series. As per criterion, Kao (1999) test accepts the alternative hypothesis of cointegration presence when test statistics value is -1.69 having $\mathrm{p}<0.05$. The results are suggestive from empirical evidence that the stock prices of eight leading Pakistani banks, market index, exchange and interest rates are found to be panel cointegrated.

Table 3 presents the Pedroni $(1999,2004)$ panel cointegration test results that was applied with the aim of robustness check. The null hypothesis for the test assumes absence of cointegration among study series. After analysis, it was found that null hypothesis is rejected at $5 \%$ for seven series out of eight series and rejected for three at $10 \%$. The group ADF-statistics is the only one that depicts absence of cointegration. Overall, the data series are strong case of cointegration sustenance as per the statistical evidence resulting 
from Pedroni panel cointegration test. Hence, the long-run association among penal series is ascertained.

\begin{tabular}{lll}
$\begin{array}{l}\text { Table 3 } \\
\text { Results of Panel Cointegration Test } \\
\text { (Pedroni, 2004) }\end{array}$ \\
\hline Panel Coefficients & Statistic & P-value \\
\hline $\mathrm{v}$ & $1.7156^{* *}$ & {$[0.0431]$} \\
rho & $-1.8562^{* *}$ & {$[0.0317]$} \\
$\mathrm{PP}$ & $-1.8603^{* *}$ & {$[0.0314]$} \\
ADF & -1.0811 & {$[0.1398]$} \\
\hline Group Coefficients & \\
\hline & & \\
rho & $-1.3478^{*}$ & {$[0.0960]$} \\
PP & $-1.6411^{*}$ & {$[0.0504]$} \\
ADF & -0.553896 & {$[0.2898]$} \\
\hline Note: $* *$, and $*$ indicate significance at the \\
Note5\% and 10\% levels, respectively.
\end{tabular}

\section{Long-Run Elasticities}

In order to check the degree of responsiveness for the variables in estimated regression, long-run elasticities were estimated and these are presented along with their t-stats in Table 4. The long-run elasticities were calculated for all variables in case of each bank and for the entire panel as well. The elasticity coefficients are quoted for each variable respectively in case of each individual bank. It is evident from the table that market index (MKR) has overall significantly positive and strong enduring effect on prices of all bank stocks, MCB and Meezan has elasticity value greater than 1, and it is lesser than 1 for the rest of six banks including the entire panel in long-run. Furthermore, the panel coefficient value depicts that stock prices of bank shoot up by $76 \%$ in case there is 1 unit increase in the market index value. On the contrary, significant inverse relation can be detected at $1 \%$ level for stock prices and exchange rate relationship for all banks and panel. Excluding Meezan Bank, the exchange rate elasticity coefficients of other series including panel lie somewhere between -1.90 and -5.324. It is noteworthy after penal analysis that Pakistani currency depreciation in contrast to exchange rate correspondingly results in bank stock prices decline. It can be assessed that 3.3\% decline in bank stock prices is caused by $1 \%$ depreciation of Pakistani currency. The interest rate elasticity coefficients nevertheless provided almost same evidence but with lower degree. Statistically significant relationship can be found for all the banks excluding three. In short, interest rate variation panel elasticity is significant at $5 \%$, whereas market index and exchange rate long-run penal elasticities have compliance of statistical significance at $5 \%$. It can be concluded that bank stock prices are highly responsive towards general market conditions, then for exchange rate variations and lesser towards short-run changes in interest rates. 
Table 4

Long-run elasticities

\begin{tabular}{|c|c|c|c|c|}
\hline & In ER & In IR & In MKR & $R^{2}$ \\
\hline BAFL & $\begin{array}{c}-3.037^{* * *} \\
(-15.47)\end{array}$ & $\begin{array}{c}-0.630 * * * \\
(-4.30)\end{array}$ & $\begin{array}{c}0.864^{* * *} \\
(-8.84)\end{array}$ & 0.851 \\
\hline BAHL & $\begin{array}{c}-1.946^{* * *} \\
(-20.30)\end{array}$ & $\begin{array}{l}-0.016 \\
(-0.23)\end{array}$ & $\begin{array}{c}0.509^{* * *} \\
(-10.67)\end{array}$ & 0.874 \\
\hline BOP & $\begin{array}{c}-5.324^{* * *} \\
(-23.35)\end{array}$ & $\begin{array}{c}-0.730^{* * *} \\
(-4.30)\end{array}$ & $\begin{array}{c}0.776^{* * *} \\
(-6.84)\end{array}$ & 0.923 \\
\hline FBL & $\begin{array}{c}-4.384^{* * * *} \\
(-31.50)\end{array}$ & $\begin{array}{l}-0.115 \\
(-1.12)\end{array}$ & $\begin{array}{c}0.629 * * * \\
(-9.09)\end{array}$ & 0.948 \\
\hline $\mathrm{MCB}$ & $\begin{array}{c}-1.881^{* * *} \\
(-14.40)\end{array}$ & $\begin{array}{c}1.333^{* * *} \\
(-13.7)\end{array}$ & $\begin{array}{c}1.298^{* * *} * \\
(-19.96)\end{array}$ & 0.802 \\
\hline MBL & $\begin{array}{c}-0.906^{* * *} \\
(-6.29)\end{array}$ & $\begin{array}{c}0.143 \\
(-1.33)\end{array}$ & $\begin{array}{c}1.097^{* * *} * \\
(-15.31)\end{array}$ & 0.707 \\
\hline NBP & $\begin{array}{c}-4.050 * * * \\
(-26.04)\end{array}$ & $\begin{array}{c}0.563^{* * *} \\
(-4.86)\end{array}$ & $\begin{array}{c}0.768^{* * *} \\
(-9.93)\end{array}$ & 0.902 \\
\hline NIB & $\begin{array}{c}-4.707^{* * *} \\
(-20.41)\end{array}$ & $\begin{array}{c}-.775^{* * *} \\
(-4.51)\end{array}$ & $\begin{array}{c}0.101 \\
(-0.89)\end{array}$ & 0.915 \\
\hline Panel & $\begin{array}{c}-3.279^{* * *} \\
(-11.60)\end{array}$ & $\begin{array}{c}-.0285^{* *} \\
(-2.14)\end{array}$ & $\begin{array}{c}0.755^{* * *} \\
(-5.37)\end{array}$ & 0.219 \\
\hline
\end{tabular}

$$
\begin{aligned}
& \Delta Y_{i t}=\beta_{1 i}+\sum_{j=1}^{k} \beta_{11 i j} \Delta Y_{i, t-j}+\sum_{j=1}^{k} \beta_{12 i j} \Delta X_{i, t-j}+\lambda_{1 i} \varepsilon_{i t-1}+\mu_{1 i t} \\
& \Delta X_{i t}=\beta_{2 i}+\sum_{j=1}^{k} \beta_{21 i j} \Delta X_{i, t-j}+\sum_{j=1}^{k} \beta_{22 i j} \Delta Y_{i, t-j}+\lambda_{2 i} \varepsilon_{i t-1}+\mu_{2 i t}
\end{aligned}
$$

The lagged residual terms $\left(\epsilon_{i t-1}\right)$ as given in above equation are deliberated by using long-run models:

$$
Y_{i t}=\alpha_{1 i}+\alpha_{2 i} X_{i t}+\varepsilon_{i t} \text { and } X_{i t}=\alpha_{1 i}+\alpha_{2 i} Y_{i t}+\varepsilon_{i t},
$$

This is done to analyze the speed of adjustment in direction of equilibrium attainment. Engle and Granger (1987) also used the time series system in same manner for application of Granger causality test in a panel and in their opinion, minimum one of adjustment coefficients are required to be non-zero for the establishment of long-run association.

For testing of null hypothesis, group means (GM) test suggested by Canning and Pedroni (2008) was applied to calculate penal test statistics. The working of individual operating entities constituting the panel are actually averaged out by applying GM test. The GM estimators assume a normal distribution under the null hypothesis of absence of long-term causal association. The panel causality test results i.e. GM estimators along with their respective signs are reported in Table 5. It is evident from the table that long-term causality runs to bank stock prices (SP) only from market index (MKT) and is significant at $1 \%$ level of significance. 
Table 5

Results of Panel Causality Test

\begin{tabular}{cccc}
\hline Test & p-value & Test & p-value \\
\hline$\lambda_{1}: M K T_{i t} \rightarrow S P_{i t}$ & $\lambda_{2}: S P_{i t} \rightarrow M K T_{i t}$ \\
$-0.026^{* * *}$ & {$[0.012]$} & -0.005 & {$[0.240]$} \\
$\lambda_{1}: E R_{i t} \rightarrow S P_{i t}$ & $\lambda_{2}: S P i t \rightarrow E R_{i t}$ \\
$-0.087^{* * *}[0.000]$ & 0.002 & {$[0.352]$} \\
$\lambda_{1}: I R_{i t} \rightarrow S P_{i t}$ & $\lambda_{2}: S R_{i t} \rightarrow I P_{i t}$ \\
$-0.061^{* * *}[0.000]$ & $-0.097^{* * *}$ & {$[0.000]$} \\
\hline \multicolumn{2}{l}{ Note: ${ }^{* * *}$ denotes statistical significance at the $1 \%$ level. }
\end{tabular}

\section{Conclusion}

The current study used panel data co integration and causality models and investigated the determinants of banking sector stock prices and returns in Pakistan. The main contribution of the study towards banking sector literature is application of Granger causality methodology and thus revealing the causality direction in the stock prices of this sector in Pakistan. For this purpose, the application of technique established by Canning and Pedroni (2008) is another contribution to banking sector literature.

After analysis, statistically significant and positive influence of market index was found on the stock prices of largest eight commercial banks in Pakistan. However, significantly negative impact of exchange rate and short-term interest rates was detected over the same stock prices. Stock prices of banks are found to be more sensitive towards the general market conditions in comparison to interest rates and exchange rates. While testing for panel, all determinants proved to be significant movers. In the end, for Granger-Causality detection in panel, the stock prices of all eight largest banks of Pakistan were found to be Granger caused by all three factors. Furthermore, except the case of nominal interest rate, unidirectional causality in stock prices was witnessed. The findings of the current study are aligned with the nominal contractual hypothesis.

The last two decades indicate that the operating environment of banking sector has experienced major transformations throughout the globe. Particularly, the banking sector of Pakistan during this period has gone through major changes in its structure and ownership such as, privatization of various banks. Moreover, the banking sector of Pakistan has also witnessed influx of number of foreign financial institutions. Regardless of these major developments, the role of sector is still at the core of financing the economic activities. However, the findings of the study have important implications from the perspective of portfolio construction and management. It is suggested that both anticipated and unanticipated variations in exchange rates and interest rates may be considered by the portfolio managers when they contemplate the diversification of client's portfolio by analyzing the appropriateness of banks share for inclusion in portfolio.

The findings of the study may help investors in devising the domestic as well as international portfolio diversification strategies. Moreover, the investment managers can rebalanced their portfolios by considering the fluctuations in the interest and exchange rates. The adverse change in macroeconomic variables need serious attention of bank managers while formulating risk management policies. The financial tools that can help in hedging the risk of bank can be tackled by taking somewhere short and sometimes long positions 
in currency swap contracts, improved asset-liability ratio management, and interest rate future contracts. But, if the selection of these futures, swaps and options will be well-timed and economical, while choosing appropriate long or short position, only then the hedging coupled with enhanced cash flows will take place. The attention of regulators is imperative for not only enhancing and improving the variety and availability of derivatives but also by developing governing mechanisms for facilitation of these tools and markets including access and efficiency of derivative markets. This will enhance and improve the banking sector sustainability in Pakistan. Moreover, the interest rate variations may be monitored and retained to minimal through monetary policy controls. The changes in central bank discount rate may be designed to follow a target rate so that variations can be anticipated by the market participants. 


\section{References}

Apergis, N., \& Eleftheriou, S. (2002). Interest rates, inflation, and stock prices: The case of the Athens stock exchange. Journal of Policy Modeling, 24(3), 231-236.

Asprem, M. (1989). Stock prices, asset portfolios and macroeconomic variables in ten European countries. Journal of Banking \& Finance, 13(4), 589-612.

Bach, G. L., \& Ando, A. (1957). The redistributional effects of inflation. The Review of Economics and Statistics, 39(1), 1-13.

Bae, S. C. (1990). Interest rate changes and common stock returns of financial institutions: Revisited. Journal of Financial Research, 13(1), 71-79.

Booth, J. R., \& Officer, D. T. (1985). Expectations, interest rates, and commercial bank stocks. Journal of Financial Research, 8(1), 51-58.

Breitung, J. (2001). The local power of some unit root tests for panel data. Emerald Group Publishing Limited.

Bulmash, S. B., \& Trivoli, G. W. (1991). Time-lagged interactions between stocks prices and selected economic variables. The Journal of Portfolio Management, 17(4), 6167.

Canning, D., \& Pedroni, P. (2008). Infrastructure, long-run economic growth and causality tests for cointegrated panels. The Manchester School, 76 (5), 504-527.

Chamberlain, S., Howe, J. S., \& Popper, H. (1997). The exchange rate exposure of US and Japanese banking institutions. Journal of Banking 6 Finance, 21 (6), 871-892.

Chance, D. M., \& Lane, W. R. (1980). A re-examination of interest rate sensitivity in the common stocks of financial institutions. Journal of Financial Research, 3(1), 49-55.

Choi, J. J., Elyasiani, E., \& Kopecky, K. J. (1992). The sensitivity of bank stock returns to market, interest and exchange rate risks. Journal of Banking $\&$ Finance, 16(5), 983-1004.

Dornbusch, R., \& Fischer, S. (1980). Exchange rates and the current account. The American Economic Review, 70(5), 960-971.

Engle, R. F., \& Granger, C. W. (1987). Co-integration and error corection: Representation, estimation, and testing. Econometrica: Journal of the Econometric Society, 55, 7625.

Fama, E. F., \& Schwert, G. W. (1977). Asset returns and inflation. Journal of Financial Economics, 5(2), 115-146.

Flannery, M. J., Hameed, A. S., \& Harjes, R. H. (1997). Asset pricing, time-varying risk premia and interest rate risk. Journal of Banking \& Finance, 21(3), 315-335.

Flannery, M. J., \& James, C. M. (1984). The effect of interest rate changes on the common stock returns of financial institutions. The Journal of Finance, 39(4), 1141-1153.

French, K. R., Ruback, R. S., \& Schwert, G. W. (1983). Effects of nominal contracting on stock returns. Journal of Political Economy, 91(1), 70-96.

Gilkeson, J. H., \& Smith, S. D. (1992). The convexity trap: pitfalls in financing mortgage portfolios and related securities. Economic Review-Federal Reserve Bank of Atlanta, r7 (6), 14-27.

Grammatikos, T., Saunders, A., \& Swary, I. (1986). Returns and risks of US bank foreign currency activities. The Journal of Finance, 41(3), 671-682. 
Hahm, J.-H. (2004). Interest rate and exchange rate exposures of banking institutions in pre-crisis Korea. Applied Economics, 36 (13), 1409-1419.

Haque, N. U. (1997). Financial market reform in Pakistan. The Pakistan Development Review, 839-854.

Im, K. S., Pesaran, M. H., \& Shin, Y. (2003). Testing for unit roots in heterogeneous panels. Journal of Econometrics, 115(1), 53-74.

Kao, C. (1999). Spurious regression and residual-based tests for cointegration in panel data. Journal of Econometrics, 90(1), 1-44.

Kessel, R. A. (1956). Inflation-caused wealth redistribution: A test of a hypothesis. The American Economic Review, 46(1), 128-141.

Kessel, R. A., \& Alchian, A. A. (1960). The meaning and validity of the inflation-induced lag of wages behind prices. The American Economic Review, 50(1), 43-66.

Khan, S. R., \& Aftab, S. (1994). Assessing the impact of financial reforms on Pakistan economy. Pakistan Journal of Applied Economics, 10(1), 99-116.

Kwan, S. H. (1991). Re-examination of interest rate sensitivity of commercial bank stock returns using a random coefficient model. Journal of Financial Services Research, $5(1), 61-76$.

Levin, A., Lin, C. F., \& Chu, C. S. J. (2002). Unit root tests in panel data: Asymptotic and finite-sample properties. Journal of Econometrics, 108(1), 1-24.

Lloyd, W. P., \& Shick, R. A. (1977). A test of stone's two-index model of returns. Journal of Financial and Quantitative Analysis, 12(3), 363-376.

Lynge, M. J., \& Zumwalt, J. K. (1980). An empirical study of the interest rate sensitivity of commercial bank returns: A multi-index approach. Journal of Financial and Quantitative Analysis, 15(3), 731-742.

Markowitz, H. (1952). Portfolio selection. The Journal of Finance, 7(1), 77-91.

Merton, R. C. (1973). An intertemporal capital asset pricing model. Econometrica: Journal of the Econometric Society, 867-887.

Narayan, P. K., Narayan, S., \& Singh, H. (2014). The determinants of stock prices: New evidence from the Indian banking sector. Emerging Markets Finance and Trade, $50(2), 5-15$.

Pedroni, P. (1999). Critical values for cointegration tests in heterogeneous panels with multiple regressors. Oxford Bulletin of Economics and Statistics, 61 (1), 653-670.

Pedroni, P. (2004). Panel cointegration: Asymptotic and finite sample properties of pooled time series tests with an application to the PPP hypothesis. Econometric Theory, $20(3), 597-625$.

Saldanli, A., Aydin, M., \& Bektas, H. (2017). The determinants of stock prices: Evidence from the Turkish banking sector. Theoretical and Applied Economics, 22(1), 181188.

Saunders, A., \& Yourougou, P. (1990). Are banks special? The separation of banking from commerce and interest rate risk. Journal of Economics and Business, 42(2), 171-182.

Scott, W. L., \& Peterson, R. L. (1986). Interest rate risk and equity values of hedged and unhedged financial intermediaries. Journal of Financial Research, 9(4), 325-329. 
Shiller, R. J., \& Beltratti, A. E. (1992). Stock prices and bond yields: Can their comovements be explained in terms of present value models? Journal of Monetary Economics, 30(1), 25-46.

Viale, A. M., Kolari, J. W., \& Fraser, D. R. (2009). Common risk factors in bank stocks. Journal of Banking \& Finance, 33(3), 464-472.

Wetmore, J. L., \& Brick, J. R. (1994). Commercial bank risk: Market, interest rate, and foreign exchange. Journal of Financial Research, 17(4), 585-596.

Yourougou, P. (1990). Interest-rate risk and the pricing of depository financial intermediary common stock: Empirical evidence. Journal of Banking \& Finance, 14(4), 803-820.

Zhao, H. (2010). Dynamic relationship between exchange rate and stock price: Evidence from China. Research in International Business and Finance, 24(2), 103-112. 